BIOMEDICAL AND BIOSOCIAL ANTHROPOLOGY
Official Journal of the International Academy
of Integrative Anthropology
journal homepage: http://bba-journal.com

\title{
Intestine wall histostructure peculiarities with peritonitis and mechanical intestine obstruction (experimental study)
}

Tamm T. I., Nepomnyaschy V. V., Shakalova O. A., Barduck A. Ya. Kharkiv Medical Academy of Post-Graduate Education, Kharkiv, Ukraine

\section{ARTICLE INFO}

Received: 14 June, 2019

Accepted: 19 July, 2019

UDC: $616.381-002+616.34$

007.272]:616.34-091.8-092.9

\section{CORRESPONDING AUTHOR}

e-mail: doktor.nep@gmail.com Nepomnyaschy V. V.

\begin{abstract}
Today, the histological criteria for differential diagnosis of dynamic ileus due to peritonitis and mechanical obstruction of the intestine remain undeveloped. In this regard, the aim of the work was to establish the difference in morphological changes occurring in the intestinal wall during dynamic and mechanical ileus in the experiment. The experiment was conducted on 33 sexually mature Wistar rats. In 15 animals of the first group, mechanical ileus was modeled by ligation of the lumen of the small intestine at the middle of the distance between the duodenojejunal junction and the ileocecal angle. In 15 rats of the second group, a dynamic ileus model was formed in the form of peritonitis by introducing fecal suspension into the lumen of the abdominal cavity. The control group included 3 animals who underwent laparotomy without the formation of mechanical ileus and peritonitis. For histological examination, fragments of the intestinal wall were sampled $1 \mathrm{~cm}$ above the site of the obstruction with mechanical ileus and the portion of the small intestine with peritonitis. Statistical processing was performed in an Excel package using parametric statistics methods. It was stated that with mechanical ileus purulent inflammation develops in the intestine wall beginning from the mucous membrane spreading over wall thickness which can cause its destruction within 48 hours; with dynamical ileus purulent inflammation develops in the intestine wall, it captures particularly serous and muscle layers without causing violations of mucosa cover structure and without intestine wall destruction within 48 hours. Under experimental dynamic ileus, changes in the mucous membrane were reactive in nature and consisted of manifestations of compensatory-adaptive and regenerative processes in response to a violation of the trophism of various structures of the intestinal wall.

Keywords: acute intestine obstruction, mechanical and dynamical ileus, purulent inflammation, intestine wall histostructure.
\end{abstract}

\section{Introduction}

Currently, not all links in the pathogenesis of acute intestinal obstruction (AIO) are completely resolved. Available clinical and experimental studies are mainly devoted to etiology, microcirculation disorders in the intestinal wall, neuroendocrine regulation of peristalsis, and the source of intoxication in this disease $[1,6,9,11,14]$. However, the data characterizing morphological and functional changes in the main structural components of the intestinal wall at the cell level are presented in the literature fragmentarily $[3,12,17,18]$.

In this regard, the study of the fine structure of intestinal tissue, which makes it possible not only to trace the direction of changes in cells and their components, but also on their basis to analyze the role of individual mechanisms of violation of the permeability of the layers of the intestinal wall with various types of ileus, becomes especially important with $\mathrm{AIO}[4,8,15]$.

The fact that the cuticular epithelium is the main component of the epithelial lining of the small intestine has been known for a long time. But so far there is no convincing data on the differences in the changes in the intestinal wall during dynamic ileus due to peritonitis and mechanical obstruction of the intestine, which could become criteria in the differential diagnosis of these two types of ileus [15].

The purpose of the work is to establish the difference in morphological changes occurring in the intestinal wall during dynamic and mechanical ileus in the experiment.

\section{Materials and methods}

The experiment was carried out on 33 sexually mature Wistar rats weighing $210-230 \mathrm{~g}$, which were divided into 2 
groups. In the first group, mechanical ileus (15 animals) was modeled by ligation of the lumen of the small intestine at the middle of the distance between the duodenojejunal junction and the ileocecal angle according to the generally accepted method [13] (Fig. 1).

A model of dynamic ileus in the form of peritonitis was formed by introducing fecal suspension into the lumen of the abdominal cavity of 15 rats [7, 13] (Fig. 2).

The control group included 3 animals who underwent laparotomy without the formation of mechanical ileus and peritonitis.

The operation was performed under general anesthesia in the operating room with the observance of aseptic and antiseptic. After the formation of mechanical and dynamic ileus, animals were taken out of the experiment after 6,12 , 24,36 , and 48 hours. For histological examination, fragments of the intestinal wall were sampled $1 \mathrm{~cm}$ above the site of the obstruction with mechanical ileus and the portion of the small intestine with peritonitis. Statistical processing was carried out in the Excel package using parametric statistics methods.

All manipulations in the experiment were performed in accordance with international requirements for conducting experimental research (Geneva 2004) and the law of Ukraine "About protection of animals from cruel treatment" dated February 21, 2006 No. 3477.

\section{Results}

During histological examination, after 6 hours of the existence of mechanical ileus, changes occur on the part of the mucous membrane - its thickness decreases to $0.402 \pm 0.051 \mathrm{~mm}$, due to an increase in the intestinal lumen. The ratio of the villi of the mucous membrane to the length of the crypts is $2 / 1$ (normal 2.5/1), and the thickness of the villi reaches $0.115 \pm 0.011 \mathrm{~mm}$, which indicates the processes of swelling that occur in the mucous membrane. At the same time, the number of lymphocytes in the own villus plate increased and amounted to $25.0 \pm 6.4$ per villus, instead of $15.0 \pm 4.1$ in the normal state (Fig. 3).

At the same time, on the model of dynamic obstruction (peritonitis), the structure of the small intestine was not histologically changed.

After 12 hours of the existence of mechanical AlO, a progressive inflammation of the mucous membrane was found in the histostructure of the wall of the adducting intestine: its thickness decreased to $0.390 \pm 0.060 \mathrm{~mm}$, which was caused by an increase in the lumen of the intestine and, as a consequence, by extension of its walls. In this case, the villus thickness increased to $0.135 \pm 0.014$ $\mathrm{mm}$, and the ratio of villus height to crypt length was halved, which amounted to $1.9: 1$, and the height of the limbic enterocytes decreased to $28.73 \pm 0.52 \mu \mathrm{m}$. It should be emphasized that during these periods the thickness of the muscle layer did not change, which amounted to $0.051 \pm 0.020 \mathrm{~mm}$. This suggests that the contractility of the intestinal wall has not been lost, since its muscle layer

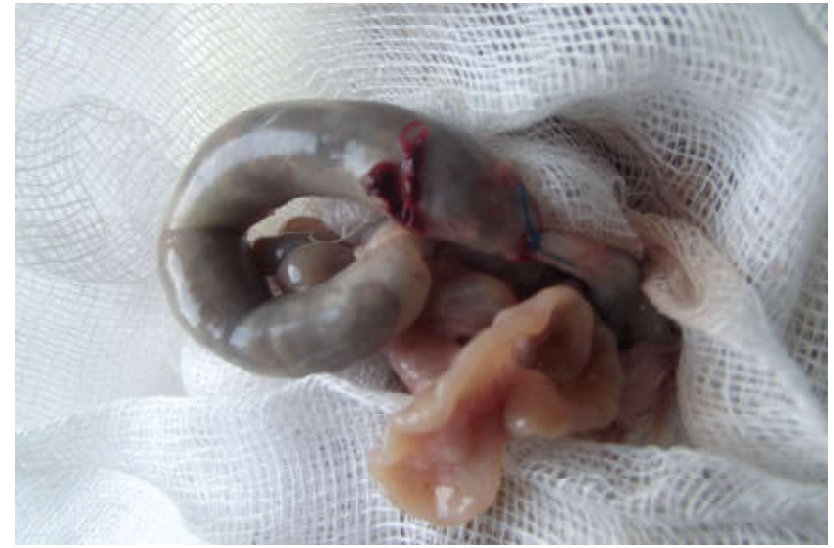

Fig. 1. The formation of mechanical ileus.

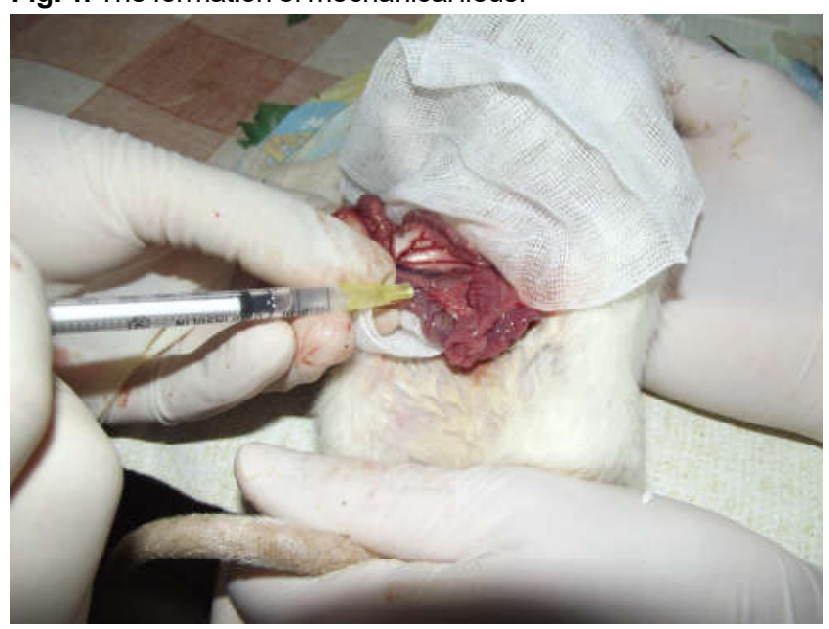

Fig. 2. The introduction of fecal suspension into the abdominal cavity of the animal.

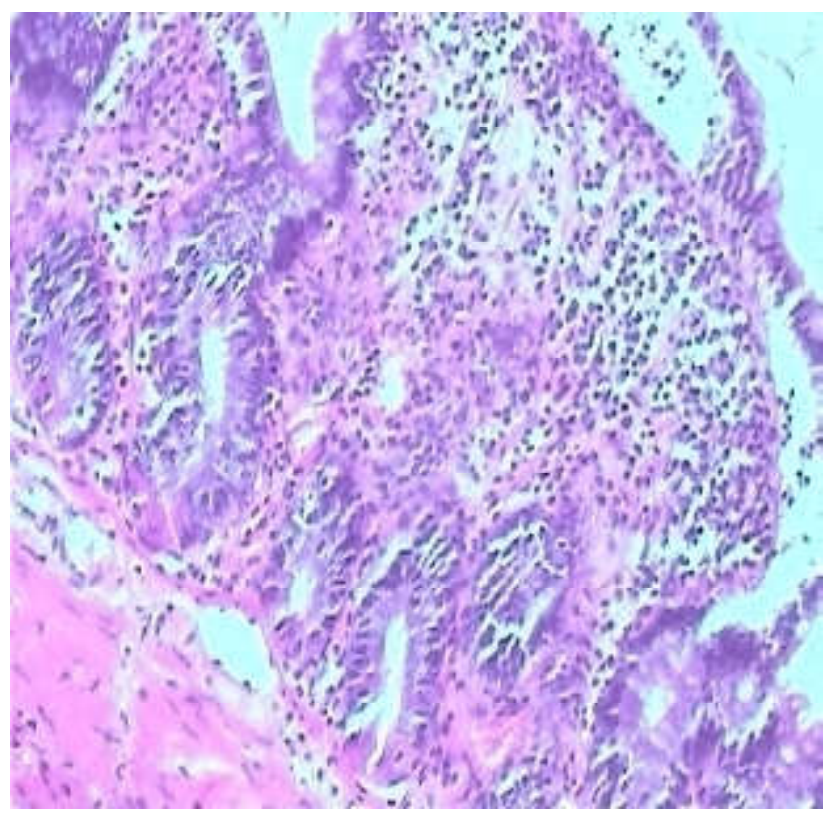

Fig. 3. Histological structure of the mucous membrane of experimental mechanical obstruction: lymphoid-leukocyte infiltration of the stroma of thickened villi with desquamated integumentary epithelium of their apices ( 6 hours). Hematoxylin and eosin stain. x180. 
was without signs of degeneration. At the same time, the brush border of enterocytes over the greater length of the villi was almost absent, and focal accumulations of bacteria were detected on the surface of the epithelium.

The cellular composition in the structure of the mucous membrane also changed in the direction of increasing the number of interepithelial lymphocytes, the number of which at these times was $185.0 \pm 29.0$ per 1000 epithelial cells. Edema of the villus own lamina is so pronounced that edematous fluid in places exfoliates them from the integument epithelium. Among lymphocytes, the number of which was $35.1 \pm 12.3$ per villus, there appeared separate, and in some places groups of neutrophilic leukocytes. White blood cell groups were also determined in the epithelial lining of the villi. As a sign of inflammation, there is a pronounced expansion and plethora of blood vessels that occurred during these periods, mainly of the small veins of the submucosal layer, in some of them regional leukostasis are detected (Fig. 4).

In the group of animals with dynamic ileus on the background of peritonitis after 12 hours, a certain decrease in the thickness of the intestinal wall was revealed with a significant expansion of its lumen. The thickness of the mucous membrane decreased to $0.37 \mathrm{~mm}$, while the thickness of the submucosal layer increased slightly, amounting to $50 \mu \mathrm{m}$. The muscle layer as a whole was thinned to $310 \mu \mathrm{m}$, mostly due to the circular layer - $220 \mu \mathrm{m}$, while the thickness of the longitudinal layer decreased slightly - $90 \mu \mathrm{m}$. The thickness of the serous membrane more than doubled, amounting to 52 microns.

When assessing changes in the mucous membrane, it was revealed that the number of crypts of Lieberkühn changed in direct proportion to the expansion of the intestinal lumen. Crypt of Lieberkühn, in micropreparations mostly represented by glands, were round or oval in shape, as in the previous study group, but their number in one field of view at an average magnification of the microscope decreased. The cellular composition of the intestinal epithelium has changed slightly. The integumentary epithelium as before consisted mainly of suction cylindrical cells with a clearly distinguishable brush border, with an admixture of goblet cells, the number of which increased as it shifted to the basal sections of the crypts. The ratio of the above-mentioned cell types was, as in the previous group, 1:4. Closer to the basal sections of the crypts, isolated representatives of endocrine and Paneth cells were found. The stem cell zone, in comparison with the previous group, increased slightly, completely capturing the basal sections of the intestinal crypts. Stem cells showed enlarged nuclei with lumpy or block chromatin, and single mitoses were present.

Own plate of the mucous membrane showed the phenomenon of moderate edema with some expansion of the gaps of the capillaries and lymphatic vessels. Its cellular composition was represented by fibroblasts, eosinophils, macrophages and segmented leukocytes, with which the

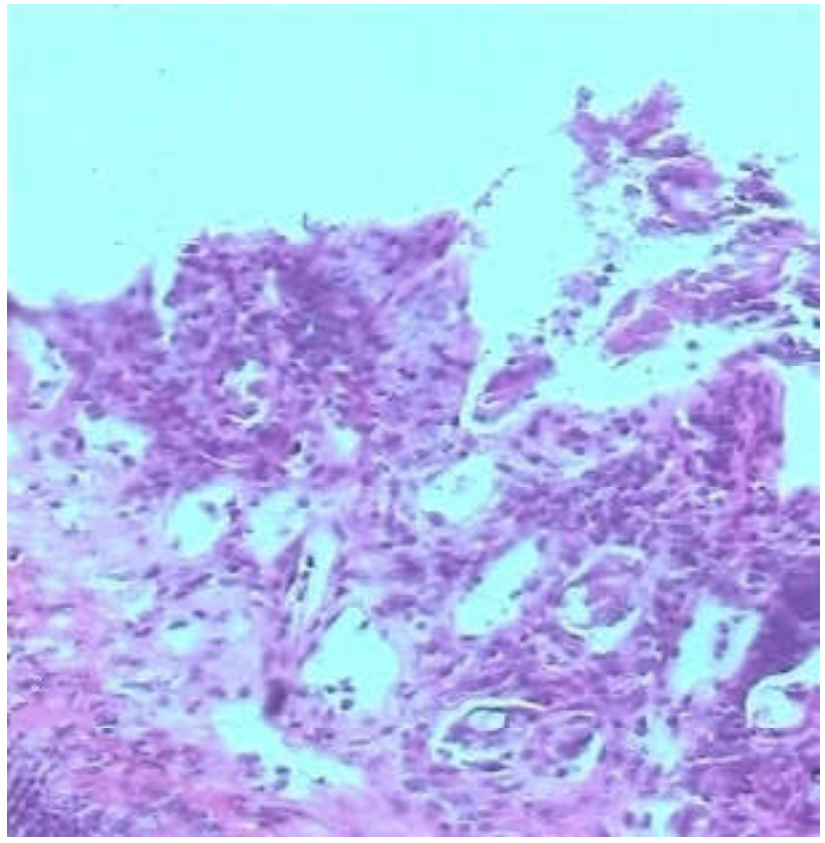

Fig. 4. The histostructure of the wall of the small intestine with mechanical AIO: edema of the stroma of the villi, lymphocyticleukocyte infiltration of their stroma (12 hours). Hematoxylin and eosin stain. $x 180$.

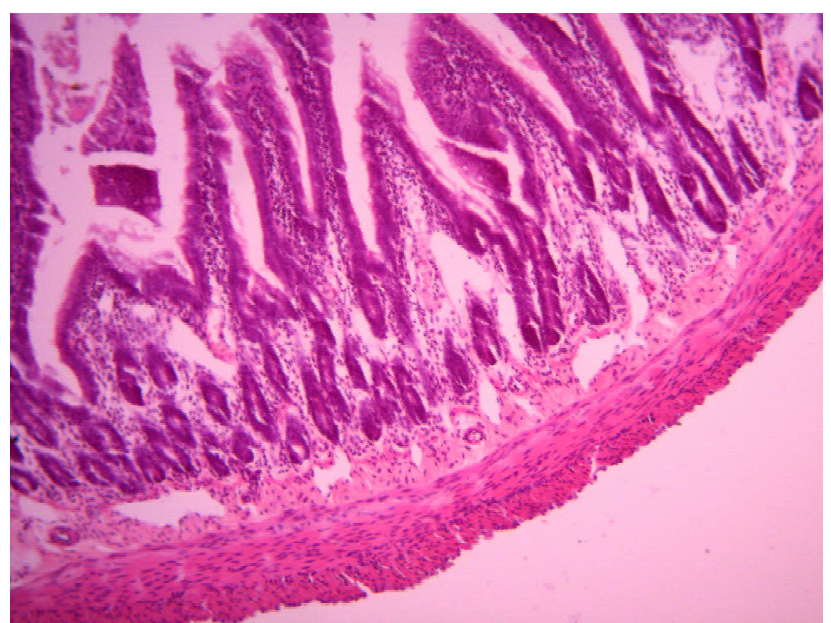

Fig. 5. Moderately pronounced edema of the lamina propria mucosa and submucosa, dynamic ileus (12 hours). Hematoxylin and eosin stain. $\times 200$.

mucous membrane of its own was infiltrated.

In the submucosa, signs of edema were determined, with moderate ectasia of small-sized capillaries and veins, in which the marginal standing of leukocytes was determined. In the upper divisions of the submucosal base, an insignificant number of inflammatory cells was found that migrated there from their own plate of the mucosa (Fig. 5).

The muscle layer of the wall was not changed in comparison with the norm.

In the serous membrane, pronounced plethora was found with the marginal standing of leukocytes, which 


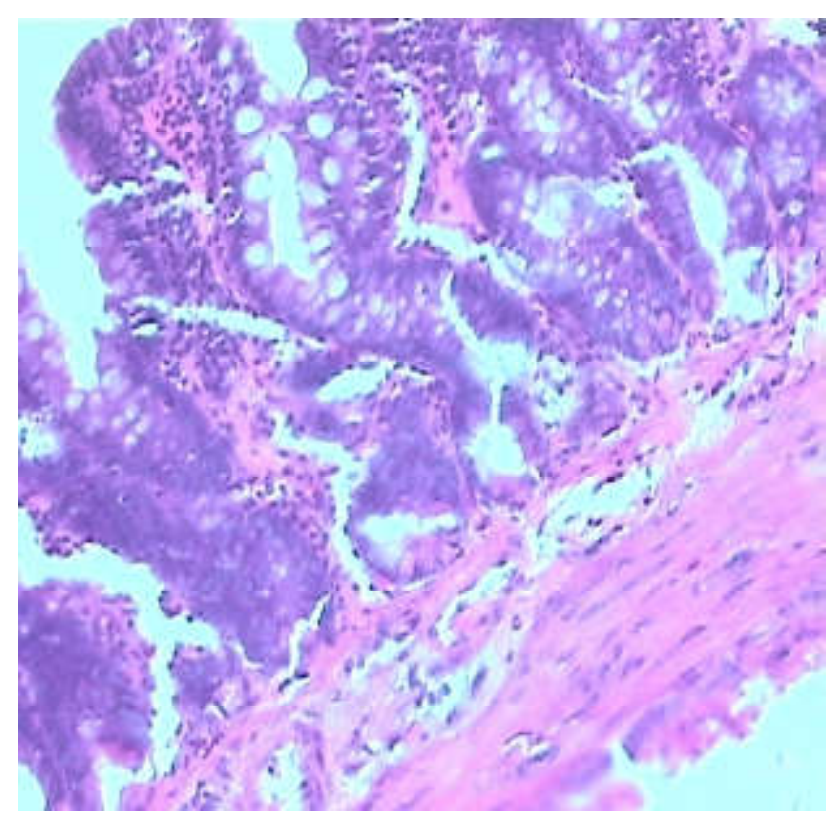

Fig. 6. Histological structure of the intestinal mucosa in mechanical AIO: partial detachment of the integumentary epithelium, lymphocytic-leukocyte infiltration of villus stroma, vascular leukostasis (24 hours). Hematoxylin and eosin stain. x180.

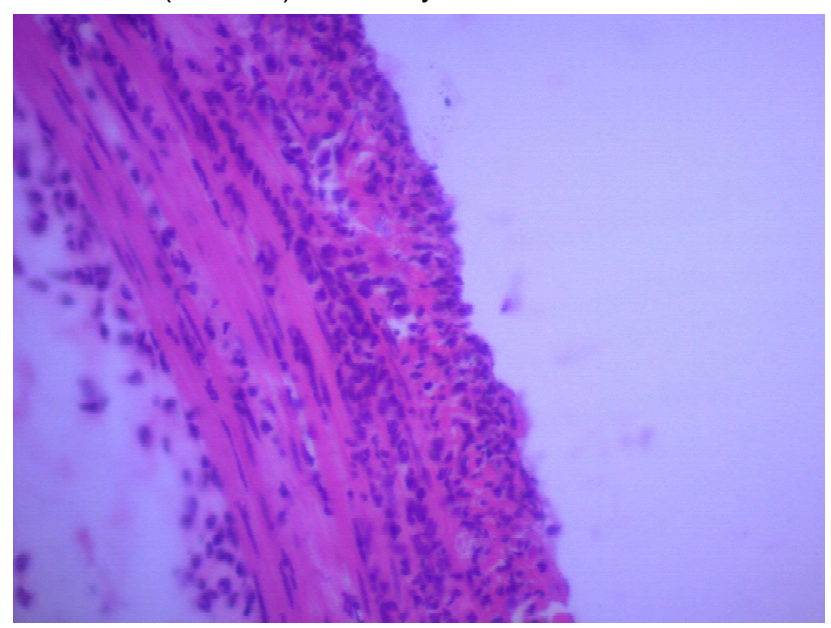

Fig. 7. Dynamic ileus (peritonitis). Migration of segmented neutrophils from the serous membrane to the muscle layer of the intestinal wall (24 hours). Hematoxylin and eosin stain. $x 400$.

indicated fibrinous-purulent inflammation. The latter manifested itself in the form of linear eosinophilic fibrin deposits, which form strata on the serous membrane with the presence in the thickness of a moderate number of neutrophilic leukocytes mixed with lymphocytes and red blood cells.

After 24 hours of mechanical ileus, an increase in purulent inflammation was detected in the intestinal biopsy samples. This was expressed in a decrease in the thickness of the mucous membrane to $0.351 \pm 0.062 \mathrm{~mm}$ due to a progressive increase in the diameter of the intestinal segment above the obstacle, a sharp increase in the thickness of the villi from the surface of which the epithelial cover was peeled off. At the same time, abundant bacterial colonies were found on the surface of the villi (Fig. 6).

After 24 hours from the beginning of the formation of dynamic ileus, an increase in edematous inflammatory dynamic changes was noted in the intestinal wall. The wall thickness continued to decrease, and the mucous membrane was thinned to $0.34 \mathrm{~mm}$, the submucosal base thickness remained at the same level, amounting to about $50 \mu \mathrm{m}$, the muscle layer was $210 \mu \mathrm{m}$ circular and 85 longitudinal. The thickness of the serous membrane increased and ranged from 60 to 110 microns.

In the mucous membrane, certain changes in the cellular composition of crypts were noted. The content of goblet cells increased in the integumentary epithelium, while the contour of the brush border lost its clarity. Certain difficulties were noted in the detection of Paneth and endocrine cells, due to the fact that the germinal area of stem cells increased, sometimes occupying up to half the length of the intestinal crypt.

In the thickness of their own plate, dense cell infiltration was determined with a clear dominance of lymphocytes, with an admixture of plasma cells, eosinophils and neutrophilic leukocytes. Cellular infiltrate tended to spread to the submucosa. The vascular network of the latter, as well as its own plate of the mucosa, was enlarged, with signs of stasis.

In the longitudinal part of the muscle layer of the intestinal wall, single neutrophilic leukocytes penetrated from the serous membrane were found (Fig. 7). The latter demonstrated the progression of purulent-necrotic

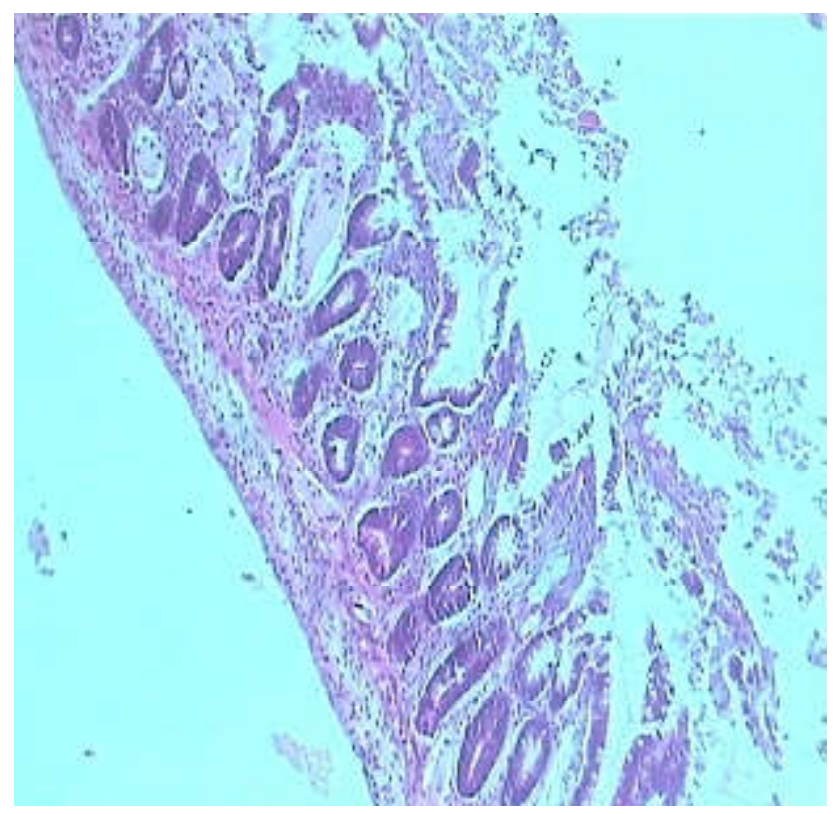

Fig. 8. Histological structure of the intestinal mucosa in mechanical AIO: total desquamation of the villus epithelium, a large number of colonies of bacteria and neutrophilic leukocytes with their translocation into the submucosal layer. (36 hours). Hematoxylin and eosin stain. $\times 100$. 


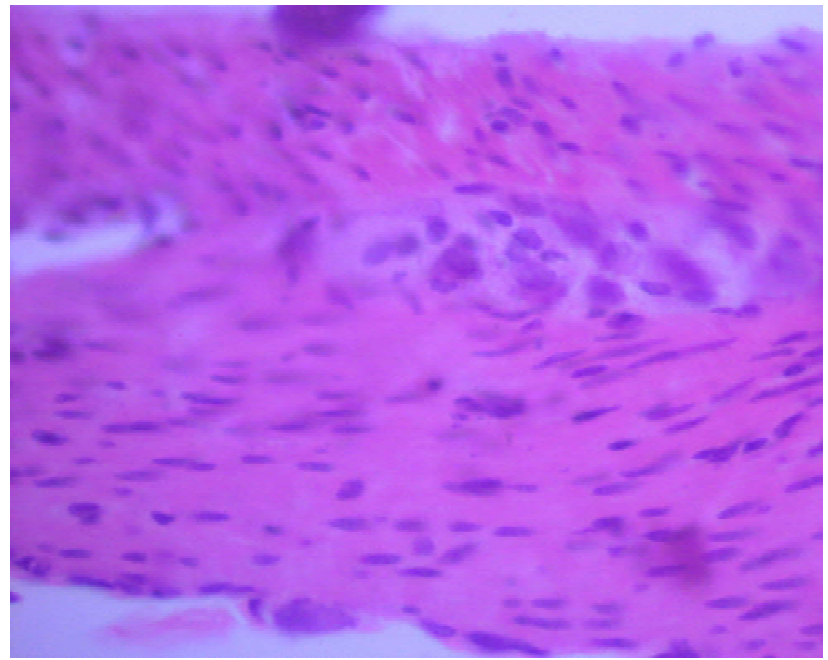

Fig. 9. Vacuolization of the cytoplasm of neurons, hypochromic staining of nuclei (36 hours). Hematoxylin and eosin stain. $x 400$.

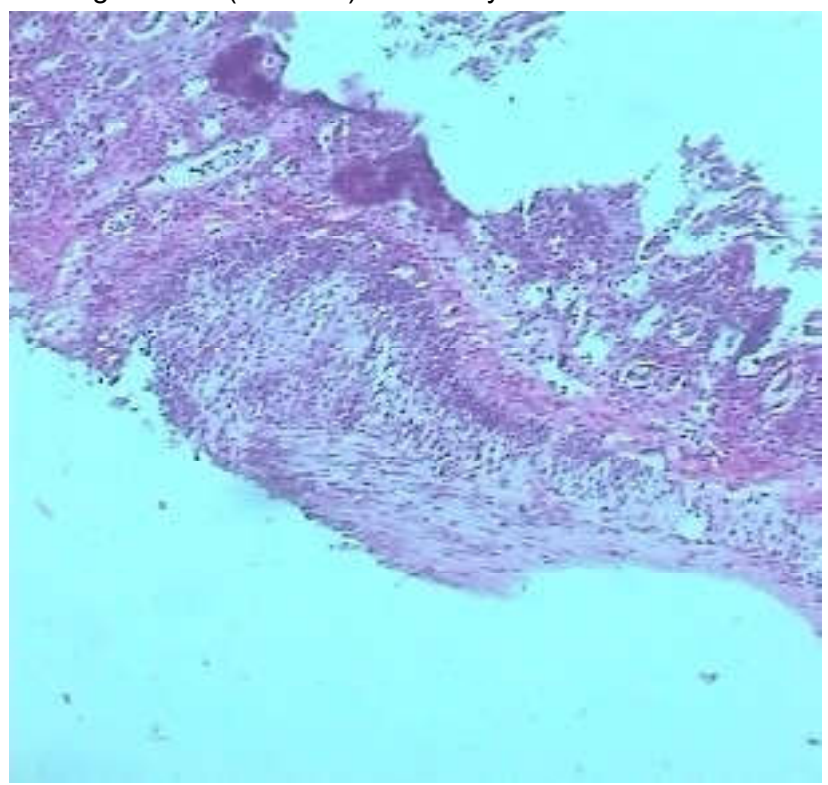

Fig. 10. Histological structure of the intestinal wall with AIO: ulcerative defect of the intestinal wall. (48 hours). Hematoxylin and eosin stain. $x 100$.

changes. Fibrin deposits had both linear and blocky structure, were abundantly infiltrated with neutrophilic leukocytes, which in some places form structures according to the type of microabscesses. Blood vessels were significantly dilated, fibrinous-leukocyte thrombi were detected in the lumen of individual vessels. Small colonies of microorganisms were determined on the surface of the serous membrane.

After 36 hours of the existence of mechanical ileus, the degenerative process in the mucous membrane was most pronounced. This was manifested by the complete absence of the integumentary epithelium of the villi, and the presence of a large number of bacteria in them with the immobilization of the stroma of the villi by polymorphic nuclear leukocytes and the penetration of microflora into the submucosal layer. The thickness of the mucous membrane of the intestinal wall during these periods decreased to $0.220 \pm 0.131 \mathrm{~mm}$. In the submucosal layer and serous membrane, sharply expanded microvessels with the marginal standing of leukocytes, the phenomena of sludge of red blood cells, and leukocyte-fibrin thrombi were determined (Fig. 8).

After 36 hours of peritonitis, as the cause of dynamic ileus, an increase in the diameter of the small intestine with a certain thinning of the structural and functional layers was noted. So, the thickness of the mucous membrane was $350-380 \mu \mathrm{m}$, of the submucosa - 30-40 $\mu \mathrm{m}$, of the circular part of the muscle layer $-280 \mu \mathrm{m}$, of the longitudinal - 80-90 $\mu \mathrm{m}$. The thickness of the serous membrane, on the contrary, was increased to $150-160 \mu \mathrm{m}$, which was due to the formation of signs of purulent inflammation in the serous membrane of the small intestine. Several shortened intestinal crypts retained their usual architectonics and cellular composition. Scanty lymphoplasmacytic infiltration, moderate vascular congestion was determined in the thickness of own plate. The latter retained their normal size and shape.

Against the background of almost unchanged structures of the muscle layer, an increase in dystrophic processes in the neurons of the Auerbach nerve plexus was noted. This was expressed in the assumption by cells of a predominantly spherical shape, the appearance of optically empty small and medium sized vacuoles in the cytoplasm, hypochromic coloring of slightly enlarged nuclei (Fig. 9).

After 48 hours of the existence of mechanical ileus, the thickness of the villi in the animals studied is almost impossible to determine due to total desquamation of the integumentary epithelium, as well as severe stromal imbibition with their polymorphonuclear leukocytes with a large number of colonies of microorganisms on the mucosal surface with "immersion" of some of them in the submucous layer. Identified ulcerative defects with the seizure of the destruction zone of a significant part of the muscle layer of the intestine were surrounded by dense perifocal leukocyte infiltrate (Fig. 10), which could clinically be a sign of ulcer perforation and fecal peritonitis.

The serous membrane of the intestine was sharply edematous with the presence of focal diffuse leukocyte infiltrates. In her vessels, leukocyte-fibrin thrombi were detected. Massive areas of fibrinous-leukocyte detritus mixed with a large number of bacterial colonies were localized on the surface of the serous membrane. It should be emphasized that the individual vessels of the serous membrane in their lumen also contain colonies of bacteria.

In two animals in this group, after 48 hours, purulentinflammatory destruction of the intestinal wall was most pronounced in the form of destruction of all its layers and the presence of multiple ulcerative necrotic defects (Fig. 11).

After 48 hours of the existence of dynamic ileus, 


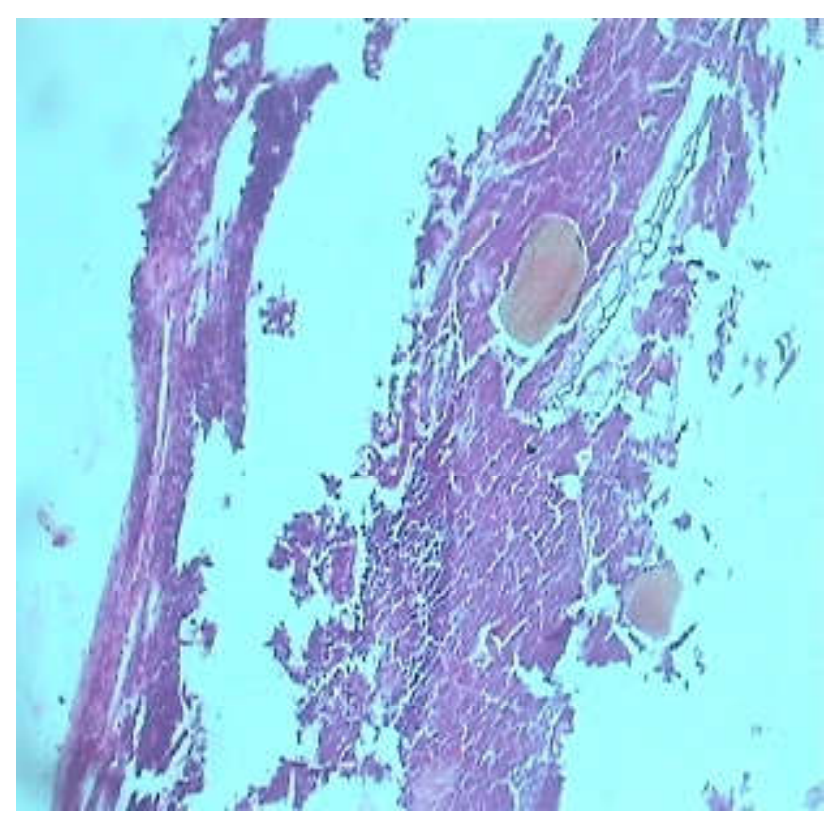

Fig. 11. Intestinal wall histostructure in mechanical AIO: total necrosis of the intestinal wall. (48 hours). Hematoxylin and eosin stain. $\mathrm{x} 100$.

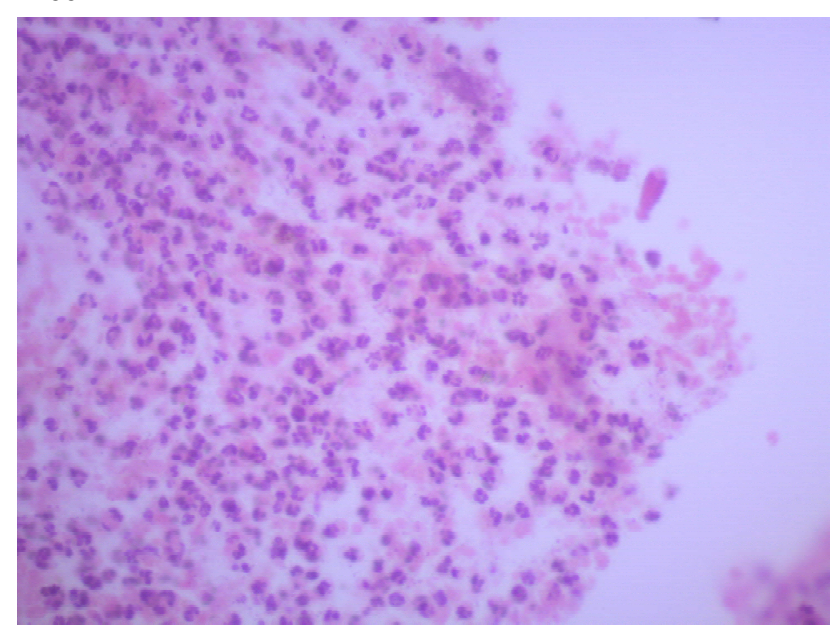

Fig. 12. Dynamic ileus. Fibrinous leukocyte detritus with the presence of colonies of microorganisms, covering the serous membrane. (48 hours). Hematoxylin and eosin stain. $x 400$.

microscopic changes showed a pronounced thinning of the intestinal wall, while the thickness of the mucous membrane did not exceed $280 \mu \mathrm{m}$, the thickness of the submucous base varied from 20 to $70 \mu \mathrm{m}$, which depended both on the severity of the edema and the density of leukocyte infiltration, which spread from the underlying muscle layer, acquiring a transmural character, sometimes capturing the entire thickness of the submucosa. The thickness of the circular muscle layer was about 180 ?m, it was often not possible to determine the thickness of the longitudinal layer because of the pronounced processes of destruction and inflammation that occur in the serous membrane and extend to the muscle layer. The serous membrane was a dense fibrinous-leukocyte detritus, in the thickness of which numerous colonies of microorganisms were determined (Fig. 12).

In the submucosa, leukocyte inflammatory infiltration was often detected, spreading from the underlying sections of the muscle layer. The latter showed a thick leukocyte infiltration, significantly violating the architectonics of this zone, which made it very difficult to clearly determine the boundary of the circular and longitudinal muscle layer. This was especially true for the boundary between the longitudinal layer and the serous membrane, since purulent destruction processes were most pronounced in this zone, which was accompanied by massive bacterial seeding of the above structures. In view of the above, it was not possible to isolate the individual structural elements of the serous membrane.

\section{Discussion}

The results of an experimental study indicate that in the case of mechanical ileus, early (after 6 hours) histological changes from the mucous membrane in the form of its swelling are detected. Histological data revealed after 12 hours of the existence of mechanical ileus, considering the presence of bacterial colonies and lymphocyticleukocyte infiltration of the intestinal mucosa, indicate the development of an inflammatory infectious process in its wall. Marked inflammatory changes in the mucosa and unchanged muscle layer indicate that with mechanical AIO, inflammation of the intestinal wall begins from the side of the mucosa. After 24 hours of the experiment, a continuous increase in purulent inflammation was detected in intestinal biopsy specimens. After 36 hours, the degenerative process in the mucous membrane was most pronounced: the absence of the integumentary epithelium of the villi, the presence of a large number of bacteria in them with the immobilization of the stroma of the villi by polymorphic nuclear leukocytes and the penetration of microflora into the submucosal layer, the presence of sharply expanded microvessels in the submucosal layer and serous membrane. After 48 hours, total desquamation of the integumentary epithelium is detected, pronounced stromal imbibition with polymorphonuclear leukocytes with a large number of microorganism colonies on the mucosal surface with the "immersion" of some of them in the submucosal layer. A significant part of the muscle layer of the intestine revealed ulcerative defects. Separate vessels of the serous membrane in the lumen contain bacteria colonies.

The study of the structure of the small intestine on the model of dynamic obstruction against the background of peritonitis after 6 hours from the beginning of the experiment showed no histological changes. The first changes, manifested by the presence of an inflammatory process in the serous membrane of the intestinal wall, signs of dynamic disturbances in the form of an expansion of the lumen and thinning of the wall, as well as a reaction of the mucosa to these changes, were recorded 12 hours after 
the start of the experiment. After 24 hours of the existence of peritonitis, the progression of the inflammatory process with the addition of a purulent-destructive component was noted, which exacerbated the violation of the functional activity of both the mucous membrane and the muscle layer. After 36 hours, there was an increase in the diameter of the small intestine with some thinning of the mucous membrane, submucosa, circular and longitudinal parts of the muscle layer. At the same time, the serous membrane was thickened, which indicated the formation of signs of purulent inflammation in it. The structure of the muscle layer is not changed. In the neurons of the Auerbach nerve plexus, an increase in dystrophic processes was noted. After 48 hours, significant progression of inflammation and the development of a massive purulent-destructive process in the intestinal wall were noted. It should be noted that the spread of acute inflammatory cell infiltration was noted according to the "outside-inside" scheme, and the serous membrane served as the initial zone. As the duration of the experiment increased, the spread of leukocyte infiltrate in the form of its "immersion" occurred in the thickness of the intestinal wall. Changes in the mucous membrane were reactive in nature and consisted of manifestations of compensatory-adaptive and regenerative processes in response to trophic disorders in various structures of the intestinal wall.

Our results supplement the available literature data that in animals with a model of experimental mechanical ileus

\section{References}

[1] Badary, D., Hassan, H., Omar, A. H., \& Ashmawy, A. (2018). A study on the pathology of acute intestinal obstruction in Upper Egypt. J. Gastroenterol. Dig. Dis., 3(1), 22-28. Retrieved from https://www.alliedacademies.org/articles/a-study-on-thepathology-of-acute-intestinal-obstruction-in-upper-egypt9947.html

[2] Bagnenko, S. F., Zakharenko, A. A., Suvorov, A. N., Shlyk, I. V., Ten, O. A., Dzhamilov, Sh. R., ... \& Rybalchenko, V. A. (2016). Perioperative changes in intestinal microbiocenosis in patients with colon cancer. Bulletin of Surgery named after I.I. Grekova, 175(6), 33-37. https://doi.org/10.24884/0042-4625-2016-1756-33-37

[3] Benedict, W. W. (2016). Causes of small bowel motility disorders in women after obstetric and gynecological operations. Prevention and treatment. Current issues of pediatrics, obstetrics and gynecology, 2(18), 33-35. Retrieved from http:/ /nbuv.gov.ua/UJRN/appatg_2016_2_11

[4] Bogun, O. A. (2010). Prevention of purulent-septic complications in patients with acute intestinal obstruction. (Dis. Ph.D.). Hark. honey. acad. postgraduate. of Education, Kharkiv.

[5] Borges-Canha, M., Portela-Cidade, J. P., Dinis-Ribeiro, M., LeiteMoreira, A. F., \& Pimentel-Nunes, P. (2015). Role of colonic microbiota in colorectal carcinogenesis: a systematic review. Rev. Esp. Enferm. Dig., 107(11), 659-671. doi: 10.17235/ reed.2015.3830/2015

[6] Jackson, P. G., \& Raiji, M. (2011). Evaluation and Management of Intestinal Obstruction. Am. Fam Physician., 83(2), 159-165. Retrieved from https://www.aafp.org/afp/2011/0115/ p159.html after 12 hours purulent inflammation develops in the intestinal wall above the site of the obstruction [4, 5, 15], which can be a source of purulent complications after the elimination of obstruction. Dynamic experimental ileus in the form of peritonitis showed that in addition to inflammation of the serous membrane in the intestinal wall, dystrophic changes of the myenteric nerve plexus occur [2, $10,16]$, which subsequently affects the ability of the intestinal wall to restore peristalsis.

The study of histostructural changes in various types of ileus requires further investigation, since in the future these changes will allow the development of differential diagnostic criteria for mechanical and dynamic acute intestinal obstruction.

\section{Conclusions}

1. In conditions of experimental mechanical ileus, purulent inflammation develops in the intestinal wall, which begins from the mucous membrane, spreading to the entire wall thickness. The intensity of the developed inflammation can lead to destruction of the intestinal wall within 48 hours.

2. In conditions of experimental dynamic ileus, caused by fecal peritonitis, purulent inflammation develops in the intestinal wall, which captures mainly the serous and muscle layer, without causing a mucosal structure violation and without causing intestinal wall destruction within 48 hours.

[7] Karkishchenko, N. N., \& Grachev, S. V. (Ed.). (2010). Guide to laboratory animals and alternative models in biomedical technology. Moscow: Medicine. Retrieved from http://scbmt.ru/ mag/rukovodstvo.pdf

[8] Lee, Y. J., Hussain, Z., Huh, C. W., Lee, Y. J., \& Park, H. (2018). Inflammation, Impaired Motility, and Permeability in a Guinea Pig Model of Postoperative lleus. J. Neurogastroenterol. Motil., 24(1), 147-158. doi: 10.5056/jnm17012.

[9] Neverov, P. S., Kondratenko, G. G., Vasilevich, A. P., \& Kudelich, O. A. (2017). Intestinal obstruction: a teaching aid. Minsk: BSMU. ISBN 978-985-567-845-9

[10] Plotnikov, Yu. V., Topuzov, E. E., Erokhina, E. A., \& Afak, T. (2017). Peritonitis from A to Z (based on the materials of the IX All-Russian Conference of the Association of General Surgeons, Yaroslavl, May 2016). Herald of Surgery named after I.I. Grekova, 176(1), 102-106. ISSN 0042-4625 (Print); ISSN 2686-7370 (Online). Retrieved from https://www.vestnikgrekova.ru/jour/article/view/305/306

[11] Russian Society of Surgeons. (2015). National Clinical Guidelines for Acute Non-Tumor Intestinal Obstruction. Rostov-on-Don: [w.p.h.].

[12] Schwarz, N. T., Beer-Stolz, D., Simmons, R. L., \& Bauer, A. J. (2002). Pathogenesis of paralytic ileus: intestinal manipulation opens a transient pathway between the intestinal lumen and the leukocytic infiltrate of the jejunal muscularis. Ann Surg., 235(1), 31-40. doi: 10.1097/00000658-200201000-00005

[13] Shalimov, S. A., Radzikhovsky, A. P., \& Keisevich, L. V. (1989). Guide to experimental surgery. Moscow: Medicine. ISBN 5225-01491-7

[14] Souvik, A., Hossein, M.Z., Amitabha, D., Nilanjan, M., \& Udipta, 
R. (2010). Etiology and Outcome of Acute Intestinal Obstruction: A Review of 367 Patients in Eastern India. Saudi J. Gastroenterol., 16(4), 285-287. doi: 10.4103/1319-3767.70617 [15] Tamm, T. I., Bardyuk, A. Ya., Govorukha, T. P., \& Repin, N. V. (2000). Comparative study of the ultrastructure of epithelial cells of the intestinal villus of the small intestine in experimental peritonitis and intestinal obstruction. Bulletin of V. N. Karazin Kharkiv National University, 494, 1, 58-60. Retrieved from https://cyberleninka.ru/article/n/sravnitelnoe-issledovanieultrastruktury-kletok-epiteliya-kishechnoy-vorsinki-tonkoykishki-pri-eksperimentalnyh-peritonite-i

[16] Vachev, A. N., Koryttsev, V. K., Shcherbatenko, V. Yu., \& Skupchenko, S. S., \& Krasnoslobodtsev, A. М. (2019).
Indications for programmed debridement relaparotomy in cases of widespread peritonitis. Bulletin of Surgery named after I. I. Grekova, 178(5), 89-94. https://doi.org/10.24884/0042-46252019-178-5-89-94

[17] Valle, R. G. L., \& Godoy, F. L. (2014). Neostigmine for acute colonic pseudo-obstruction: A meta-analysis. Annals of Medicine and Surgery, 3, 60-64. doi: 10.1016/ j.amsu.2014.04.002

[18] Vather, R., Josephson, R., Jaung, R., Robertson, J., \& Bissett, I. (2015). Development of a risk stratification system for the occurrence of prolonged postoperative ileus after colorectal surgery: A prospective risk factor analysis. Surgery, 157(4), 764-773. doi: 10.1016/j.surg.2014.12.005

\section{ОСОБЛИВОСТІ ГІСТОСТРУКТУРИ СТІНКИ КИШКИ ПРИ ПЕРИТОНІТІ ТА МЕХАНІЧНІЙ НЕПРОХІДНОСТІ КИШКІВНИКА (ЕКСПЕРИМЕНТАЛЬНЕ ДОСЛІДЖЕННЯ)}

Тамм Т. І., Непомнящий В. В., Шакалова О. А., Бардюк О. Я.

На сьогодні залишаються нерозробленими гістологічні критерії диференціальної діагностики динамічного ілеусу, обумовленого перитонітом, і механічної непрохідності кишечника. У зв'язку з цим, метою роботи було встановити відмінність морфологічних змін, що відбуваються в стінці кишки при динамічному і механічному ілеусі в експерименті. Експеримент проведено на 33 статевозрілих щурах лінії Вістар. У 15 тварин першої групи моделювали механічний ілеус шляхом перев'язки просвіту тонкої кишки на середині відстані між дуоденоеюнальним переходом та ілеоцекальним кутом. У 15 щурів другої групи шляхом введення калової суспензії в просвіт черевної порожнини формували модель динамічного ілеусу у вигляді перитоніту. До контрольної групи увійшли 3 тварини, яким виконували лапаротомію без формування механічного ілеусу і перитоніту. Для гістологічного дослідження проводили забір фрагментів стінки кишки на 1 см вище місия перешкоди при механічному ілеусі та ділянки тонкої кишки при перитоніті. Статистичну обробку здійснювали в пакеті Excel за допомогою методів параметричної статистики. Встановлено, що при механічному ілеусі в стінці кишки розвивається гнійне запалення, що починається з боку слизової оболонки, розповсюджуючись вдовж товщини стінки, яке може привести до деструкції ії протягом 48 годин; а при динамічному ілеусі в стінці кишки розвивається гнійне запалення, яке захоплює в основному серозний та м'язовий шар, не викликаючи порушення структури слизової оболонки та не викликаючи деструкції стінки кишки протягом 48 годин. В умовах експериментального динамічного ілеусу зміни слизової оболонки носили реактивний характер і складалися з проявів компенсаторно-пристосувальних і регенеративних процесів у відповідь на порушення трофріки різних структур стінки кишечнику.

Ключові слова: гостра непрохідність кишківника, механічний та динамічний ілеус, гнійне запалення, гістроструктура стінки кишки.

\section{ОСОБЕННОСТИ ГИСТОСТРУКТУРЫ СТЕНКИ КИШКИ ПРИ ПЕРИТОНИТЕ И МЕХАНИЧЕСКОЙ НЕПРОХОДИМОСТИ КИШЕЧНИКА (ЭКСПЕРИМЕНТАЛЬНОЕ ИССЛЕДОВАНИЕ) \\ Тамм Т. И., Непомнящий В. В., Шакалова Е. А., Бардюк А. Я.}

На сегодня остаются неразработанными гистологические критерии диффреренциальной диагностики динамического илеуса, обусловленного перитонитом, и механической непроходимости кишечника. В этой связи, целью работы было установить различие морфологических изменений, происходящих в стенке кишки при динамическом и механическом илеусе в эксперименте. Эксперимент проведен на 33 половозрелых крысах линии Вистар. У 15 животных первой группы моделировали механический илеус путем перевязки просвета тонкой кишки на середине расстояния между дуоденоеюнальным переходом и илеоцекальным углом. У 15 крыс второй группы путем введения каловой взвеси в просвет брюшной полости формировали модель динамического илеуса в виде перитонита. В контрольную группу вошли 3 животных, которым выполняли лапаротомию без формирования механического илеуса и перитонита. Для гистологического исследования производили забор фррагментов стенки кишки на 1 см выше места препятствия при механическом илеусе и участка тонкой кишки при перитоните. Статистическую обработку осуществляли в пакете Exсеl с помощью методов параметрической статистики. Установлено, что при механическом илеусе в стенке кишки развивается гнойное воспаление, которое начинается со стороны слизистой оболочки, распространяясь на всю толщину стенки, которое может привести к деструкции ее в течение 48 часов; а при динамическом илеусе в стенке кишки развивается гнойное воспаление, которое захватывает в основном серозный и мышечный слой, не вызывая нарушения структуры слизистой оболочки и не вызывая деструкции стенки кишки в течении 48 часов. В условиях экспериментального динамического илеуса изменения слизистой оболочки носили реактивный характер и состояли из проявлений компенсаторно-приспособительных и регенеративных процессов в ответ на нарушение трофики различных структур стенки кишки.

Ключевые слова: острая непроходимость кишечника, механический и динамический илеус, гнойное воспаление, гистоструктура стенки кишки. 